\title{
Gerhard Scherhorn, 21 February 1930-28 February 2018
}

\author{
Alan Mathios ${ }^{1}$ - Hans Micklitz ${ }^{2}$ - Lucia Reisch ${ }^{3}$. \\ John Thogersen ${ }^{4} \cdot$ Christian Twigg-Flesner $^{5}$
}

Published online: 23 April 2018

(C) Springer Science+Business Media, LLC, part of Springer Nature 2018

We regret to report the passing of one of the three founding editors of the Journal of Consumer Policy, emeritus professor of consumer theory and consumer policy at University of Hohenheim and former Director of the research group "New Models of Wealth" at Wuppertal Institute, Gerhard Scherhorn. He passed away on February 28 after a long period of illness, caused by a traffic accident in 2013 from which he never recovered. We have lost a wonderful colleague, an inspiring researcher, a supportive mentor, and a dear friend.

Gerhard Scherhorn was born in Hanover, Germany, on the 21st of February 1930. After his Abitur in Marburg/Lahn, he completed an apprenticeship as bookseller, a three-year vocational training, that laid the base for Gerhard's passion for books and publishing. He then studied economics and philosophy at the Universities of Hamburg and Cologne, where he received his doctoral degree in 1959. His supervisor was the founder of economic psychology and socioeconomics in Germany, Professor Günter Schmölders. In 1966, Gerhard also passed his habilitation, again mentored by Schmölders. In the same year, he became full professor of economics at the union-linked Hamburg "University for Economics and Politics" (Hochschule für Wirtschaft und Politik). From 1971 to 1975, he also served as its President.

During this early period, Gerhard Scherhorn's research focused on the theoretical foundations of consumer interest, consumer economics, consumer behaviour, and consumer policy. His publications related to the idea of the sovereign consumer and the concepts of needs, wants, and demand. He also became increasingly interested in empirical consumer action research. In 1975, he moved to the University of Hohenheim in Stuttgart, to become full professor of consumer theory and consumer policy. His newly set up chair was Germany's

Lucia Reisch

lre.msc@cbs.dk

Cornell University, Ithaca, NY, USA

2 European University Institute, Florence, Italy

3 Copenhagen Business School, Copenhagen, Denmark

4 Aarhus University, Aarhus, Denmark

5 School of Law, University of Warwick, Coventry CV4 7AL, UK 
only university chair with this denomination and focus. Gerhard Scherhorn contributed with an immense groundwork to these two fields, both in research and teaching.

He was also a highly demanded policy consultant: From 1974 to 1979, he served as one of the "Five Wise Men," the prestigious German Council of Economic Experts of the German government. In this council, his voice was the one that advised caution of unlimited economic growth and that advocated for the rights of nature, fair working conditions, and the needs of vulnerable consumers. Whether as insistent admonisher and visionary in environmental issues or as successful promoter of social justice and a fair market economy, Gerhard Scherhorn was certainly an inconvenient and unerring council member.

During his years in Hohenheim (1975-1998), Gerhard Scherhorn's main research interest was consumer policy, ethical consumption and production, and later sustainable development. He also produced important contributions to the understanding of consumer behaviour and the design of effective consumer policy. From the 1990s, he was engaged in the research and practice of the Good Life and how-and what type of - consumption can contribute to it. Recurring research themes were: ethical, environmental, and socially fair modes of consumption and production (today combined under the umbrella of "sustainable consumption"); wealth in time versus material wealth; hypertrophic forms of modern consumption such as shopping addiction and compensatory buying; the impact of the newly emerging electronic means of payment on needs and wants, and the policy relevance of these challenges. Most of his research culminated in the question of what policy-consumer policy, environmental policy, economic policy - can do to help increase the welfare of all, with a specific focus on vulnerable consumers.

In the late $1990 \mathrm{~s}$, he became increasingly involved in the work being carried out at the then emerging Wuppertal Institute for Climate, Environment, and Energy (headed by Ernst-Ulrich von Weizsäcker), where he became Director of the research group "New Models of Wealth" (1996-2003), and later (2003-2005) of the research group "Sustainable production and consumption". His research interest was now fully focused on the interplay between consumer behaviour and (un)sustainable development as well as the fair bequest package that each generation owes to the next. He published many books and articles, book chapters, and famous grey literature "think pieces" that he would discuss with his group of young $\mathrm{PhD}$ students and senior peers. Many of those working papers were unfortunately never published-he would only publish something that was perfect according to his rigorous judgement.

Gerhard Scherhorn also served nine years as a member of the board of the Stiftung Warentest in Berlin (1975-1984). For his achievements, Gerhard Scherhorn was honoured on many occasions over the years, including a Festschrift on the occasion of his retirement, edited by two of his former students, Michael Neuner and Lucia Reisch, published by Duncker \& Humblot in 1998 with contributions from a large number of students, scholars, and friends.

As a "father" of consumer policy research in Germany, it was obvious that Gerhard, together with legal scholar Norbert Reich and economic psychologist Folke Ölander, should be a founder of this journal in 1977. For the early decades, Gerhard served as a kind of "primus inter pares" of the three founding editors: he hosted the Editorial Office in his institute at the University of Hohenheim, and involved his experienced staff in a successful start of the journal (particularly Heiner Imkamp who served as Managing Editor for almost three decades); Gerhard organized the first publisher (Luchterhand) and, last but not least, ensured a stable flow of urgently needed monetary support from the German Ministry of Economics before the Journal succeeded and became financially independent. 
We do owe thanks to our three founding editors, all of whom have recently passed away, for their engagement, devotion, and far-sightedness in building and developing the journal through four eventful decades. After only a few changes in editorship, the journal has just celebrated its 40th anniversary. As was the case back then, the current five editors enjoy a close-knit friendship based on decades of academic work and trust. The spirit, respect, and sense of responsibility for publishing excellent and innovative research that has motivated the founders, are still an example for all of us. We are grateful that we can continue in their memory.

Gerhard has passed away, but the gratefulness for having had a dear colleague and a great researcher remains and his memory lives on. 